\title{
Prevalence of Plasmid-Mediated Quinolone Resistance Genes Among Escherichia coli in the Gut of Healthy People in Fuzhou, China
}

\author{
Bin Li, Ph.D. ${ }^{1, *}$, Yao Chen, M.D. ${ }^{1, *}$, Zhiyun Wu, M.D. ${ }^{1}$, Zhichang Zhao, M.D. ${ }^{2}$, Juan Wu, M.D. ${ }^{1}$, and Yingping Cao, Ph.D. ${ }^{1}$
} Departments of Clinical Laboratory ${ }^{1}$ and Pharmacy ${ }^{2}$, Fujian Medical University Union Hospital, Fuzhou, Fujian, China

\section{Dear Editor,}

The intestinal tract may be an important reservoir for antibioticresistant genes [1]. Determining the prevalence of quinolone resistance in intestinal bacteria within the community is important for both healthy subjects and hospital patients as quinolone is one of the most commonly used antibiotics in China. The prevalence of plasmid-mediated quinolone resistance (PMQR) geneharboring Enterobacteriaceae in the gut flora among healthy humans was previously unknown, so we assessed the prevalence of PMQR genes among commensal Escherichia coli in healthy persons from one region in China. This study was approved by the Ethics Committee of the Fujian Medical University Union Hospital (No. 2012KY085). Written informed consent was obtained from all participants.

From July to October 2013, fecal samples were collected at a teaching hospital in Fuzhou (China) from healthy subjects at their annual physical examination. None of the subjects had been exposed to antibiotics or a hospital environment in the three months prior to sample collection. A total of 429 fecal samples, one per person, were examined. Samples were screened using MacConkey agar plates supplemented with levofloxacin (0.125 $\mu \mathrm{g} / \mathrm{mL}$ ). Among the 429 participants, 220 (51.3\%) were males and $209(48.7 \%)$ were females. The age range was 6-84 years (median age: 48 years). Four participants were under 18 years old, and the rest were over 18 years.

In this study, 89.0\% (382/429) of the samples were colonized with $E$. coli with reduced quinolone susceptibility. Previous research on community carriage of quinolone-resistant Enterobacteriaceae described carriage rates that were highly different from our findings [2, 3], probably because of factors such as regional differences in climate, eating patterns, and sanitary conditions.

PMQR determinants were screened by PCR in 382 levofloxacin-resistant $E$. coli fecal isolates as previously described [4]. The results showed that $31.4 \%$ (120/382) of fecal E. coli harbored PMQR determinants. Among 120 PMQR-positive isolates, qnr genes were the most common determinants (41.7\%), followed by aac (6')-Ib-cr (36.7\%) and oqXAB (35.8\%) (Table 1). Among 50 qnr-positive E. coli, qnrS1 was the most common PMQR gene $(94.0 \%)$, as reported by previous studies [3, 4]. qnrB1 was detected in four isolates (Table 1); qnrA, qnrC, and qnrD were not found. Usually, aac $\left(6^{\prime}\right)-\mathrm{Ib}-\mathrm{Cr}$ is more common than qnr genes [5]. A previous study showed that strain selection criteria may underestimate the presence of bacteria harboring aac (6')-Ib-cr [6], which probably explains the low prevalence of this PMQR determinant in our study.
Received: August 4, 2017

Revision received: September 18, 2017

Accepted: March 12, 2018

Corresponding author: Yingping Cao

Department of Clinical Laboratory, Fujian Medical University Union Hospital, 29 Xinquan Rd., Fuzhou, Fujian, 350001, China

Tel: +86-591-86218678, E-mail: caoyingping918@hotmail.com

\section{Korean Society for Laboratory Medicine}

This is an Open Access article distributed under the terms of the Creative Commons Attribution Non-Commercial License (http://creativecommons.org/licenses/by-nc/4.0) which permits unrestricted non-commercial use, distribution, and reproduction in any medium, provided the original work is properly cited.

*These authors contributed equally to this study. 
Table 1. Distribution of PMQR genes in E. coli phylogenetic groups and the corresponding fluoroquinolone minimal inhibitory concentration (MIC) ranges

\begin{tabular}{|c|c|c|c|c|c|c|c|c|c|c|c|}
\hline \multirow{2}{*}{ PMQR genes } & \multirow{2}{*}{$\mathrm{N}$} & \multicolumn{4}{|c|}{ Phylogenetic group (N, \%) } & \multicolumn{3}{|c|}{ Ciprofloxacin ( $\mu \mathrm{g} / \mathrm{mL})$} & \multicolumn{3}{|c|}{ Levofloxacin ( $\mu \mathrm{g} / \mathrm{mL})$} \\
\hline & & A & $\mathrm{B}_{1}$ & $B_{2}$ & D & MIC range & $\mathrm{MIC}_{50}$ & $\mathrm{MIC}_{90}$ & MIC range & $\mathrm{MIC}_{50}$ & $\mathrm{MIC}_{90}$ \\
\hline$q n r S 1$ & 38 & $25(65.8)$ & $9(23.7)$ & $4(10.5)$ & 0 & $1-64$ & 4 & 32 & $1-128$ & 4 & 32 \\
\hline $\operatorname{aac}\left(6^{\prime}\right) \mid b-c r$ & 33 & $16(48.5)$ & $6(18.2)$ & $3(9.1)$ & $8(24.2)$ & $1-256$ & 32 & 128 & $2-64$ & 8 & 32 \\
\hline$o q \times A+o q \times B$ & 32 & $18(56.3)$ & $10(31.3)$ & 0 & $4(12.5)$ & $1-64$ & 8 & 32 & $1-32$ & 8 & 16 \\
\hline$q n r S 1+o q \times A+o q \times B$ & 6 & $3(50)$ & $3(50)$ & 0 & 0 & $1-8$ & 2 & 8 & $1-32$ & 4 & 32 \\
\hline $\operatorname{aac}\left(6^{\prime}\right) / b-c r+o q \times A+o q \times B$ & 4 & $2(50)$ & $2(50)$ & 0 & 0 & $8-32$ & 16 & 32 & $16-32$ & 16 & 32 \\
\hline$q n r S 1+a a c\left(6^{\prime}\right) l b-c r$ & 2 & $2(100)$ & 0 & 0 & 0 & - & - & - & - & - & - \\
\hline$q n r B 1+a a c\left(6^{\prime}\right) \mid b-c r$ & 2 & $2(100)$ & 0 & 0 & 0 & - & - & - & - & - & - \\
\hline oqXA & 1 & 0 & 0 & 0 & 1 & - & - & - & - & - & - \\
\hline$q n r S 1+q n r B 1+a a c\left(6^{\prime}\right) \mid b-c r$ & 1 & 1 & 0 & 0 & 0 & - & - & - & - & - & - \\
\hline$q n r B 1+\operatorname{aac}\left(6^{\prime}\right) / b-c r+o q \times A+o q \times B$ & 1 & 1 & 0 & 0 & 0 & - & - & - & - & - & - \\
\hline Total & 120 & $70(58.3)$ & $30(25.0)$ & $7(5.8)$ & $13(16.7)$ & & & & & & \\
\hline
\end{tabular}

Abbreviations: $\mathrm{MIC}_{50}$, minimum inhibitory concentration required to kill $50 \%$ of the microbial population; $\mathrm{MIC}$, minimum inhibitory concentration required to kill $90 \%$ of the microbial population.

Table 2. Association between antimicrobial susceptibility and $\beta$-lactamase genes in PMQR-positive E. coli isolates

\begin{tabular}{|c|c|c|c|c|c|c|c|c|c|c|}
\hline \multirow{3}{*}{$\begin{array}{l}\text { Antimicrobial } \\
\text { agents }\end{array}$} & \multirow{2}{*}{\multicolumn{3}{|c|}{ MIC ( $\mu \mathrm{g} / \mathrm{mL})$}} & \multicolumn{7}{|c|}{ Resistance rate (\%) } \\
\hline & & & & \multicolumn{2}{|c|}{$\begin{array}{c}\text { Total } \\
(\mathrm{N}=120)\end{array}$} & \multicolumn{2}{|c|}{$\begin{array}{c}\beta \text {-lactamase gene- } \\
\text { positive strains }(\mathrm{N}=99)\end{array}$} & \multicolumn{2}{|c|}{$\begin{array}{l}\beta \text {-lactamase gene-negative } \\
\text { strains }(\mathrm{N}=21)\end{array}$} & \multirow[t]{2}{*}{$P^{*}$} \\
\hline & MIC range & $\mathrm{MIC}_{50}$ & $\mathrm{MIC}_{90}$ & $S$ & $\mathrm{R}$ & $S$ & $\mathrm{R}$ & $S$ & $\mathrm{R}$ & \\
\hline Nalidixic acid & $16-512$ & 512 & 512 & 0 & 100 & 0 & 100 & 0 & 100 & - \\
\hline Ciprofloxacin & $0.5-512$ & 8 & 64 & 9.2 & 78.3 & 8.1 & 81.8 & 14.3 & 57.1 & 0.407 \\
\hline Levofloxacin & $0.5-256$ & 8 & 32 & 10.8 & 66.7 & 10.1 & 71.7 & 14.3 & 42.9 & 0.463 \\
\hline Cefotaxime & $0.125-512$ & 0.125 & 128 & 56.7 & 43.3 & 51.5 & 48.5 & 85.7 & 14.3 & 0.004 \\
\hline Gentamicin & $0.125-512$ & 2 & 128 & 52.5 & 45.8 & 49.5 & 48.5 & 71.4 & 28.6 & 0.081 \\
\hline Cefepime & $0.125-512$ & 0.125 & 8 & 92.5 & 4.2 & 92.9 & 3.0 & 95.2 & 4.8 & 0.555 \\
\hline Amikacin & $0.125-512$ & 2 & 2 & 97.5 & 2.5 & 97.0 & 3.0 & 100 & 0 & 1.000 \\
\hline Imipenem & $0.125-4$ & 0.25 & 0.5 & 100 & 0 & 100 & 0 & 100 & 0 & - \\
\hline
\end{tabular}

*Statistical significance $(P)$ was calculated using the Pearson Chi-square test in terms of the number of resistant strains and susceptible strains in the $\beta$-lactamase gene-positive and $\beta$-lactamase gene-negative groups. Intermediate isolates were considered non-susceptible isolates.

Abbreviations: S, susceptible; R, resistant; MIC, minimum inhibitory concentration; $\mathrm{MIC}_{50}$, minimum inhibitory concentration required to kill $50 \%$ of the microbial population; $\mathrm{MIC}_{90}$, minimum inhibitory concentration required to kill $90 \%$ of the microbial population.

PMQR determinants are frequently associated with extended spectrum beta-lactamase (ESBL) in Enterobacteriaceae [5]. In this study, $\beta$-lactamase genes (blaTEM, blaSHV, and blaCTX-M) were detected as described previously [7]. Ninety-nine (82.5\%) strains co-harbored $\beta$-lactamase genes. blaтем-1, blaст-м-1 group, and blacтх-м-9 group were found in 72 (72.3\%), 24 (24.2\%), and $21(21.2 \%)$ isolates, respectively. Overall, blactx-M-15 was the predominant ESBL genotype $(20.2 \%, 20 / 99)$, followed by blaстх-M-14 (13.1\%, 13/99), blaстх-м-65 $(5.1 \%, 5 / 99)$, blaстх-м-79 $(4.0 \%, 4 / 99)$, blactx-м-27 $(2.0 \%, 2 / 99)$, and blactx-м-98 $(1.0 \%, 1 / 99)$. blasнv, blactx-
M-2 group, and blactx-M-8 group were not found. Different PMQR genes tend to co-exist with specific cephalosporin resistance genes. For example, qnrA and qnrB are usually found with blaCTX-M and blaSHV, and qnrS is always located on plasmids carrying blaTEM-1 [8]. These might explain why in our study, most PMQR-positive isolates produced blaTEM-1 and less than half of the strains co-harbored blaCTX-M.

$\mathrm{PMQR}$-harboring fecal $E$. coli were tested for susceptibility toward nine different antimicrobials according to the CLSI [9]. These isolates showed high resistance against nalidixic acid (100\%, 
120/120), ciprofloxacin (78.3\%, 94/120), and levofloxacin (66.7\%, 80/120). Resistance rates to gentamicin, cefotaxime, cefepime, and amikacin were less than 50\% (Table 2). All strains were susceptible to imipenem. Antibiotic susceptibilities of $\beta$-lactamase gene-positive and $\beta$-lactamase gene-negative PMQR-positive $E$. coli are shown in Table 2. A higher percentage of resistance to cefotaxime was observed in $\beta$-lactamase gene-positive isolates than in negative isolates (Table 2).

Molecular characteristics of PMQR-positive E. coli fecal isolates were determined, including phylogenetic grouping and random amplified polymorphic DNA analysis as previously described $[2,7]$. The distribution of PMQR genes in E. coli phylogenetic groups is shown in Table 1. PMQR-positive E. coli fecal strains (120) were categorized into 71 genotypes; three strains were non-typeable, suggesting a non-clonal origin.

In conclusion, our study demonstrated a high prevalence of quinolone-resistant $E$. coli colonization in the gut flora of healthy subjects in one region of China. PMQR determinants were widely disseminated among those strains. Rational antibiotic use is imperative, and intervention programs and policies are urgently needed to control the colonization and dissemination of quinoIone-resistant Enterobacteriaceae to promote public health in China.

\section{Authors' Disclosures of Potential Conflicts of Interest}

No potential conflicts of interest relevant to this article were reported.

\section{Acknowledgment}

This study was supported by the National Natural Science Foundation of China (grant no. 81201328), and the Medical Elite Cultivation Program of Fujian, China (grant no. 2015-ZQN-ZD-15).

\section{REFERENCES}

1. Huddleston JR. Horizontal gene transfer in the human gastrointestinal tract: potential spread of antibiotic resistance genes. Infect Drug Resist 2014;7:167-76.

2. Gao L, Hu J, Zhang X, Wei L, Li S, Miao Z, et al. Application of swine manure on agricultural fields contributes to extended-spectrum $\beta$-lactamaseproducing Escherichia coli spread in Tai'an, China. Front Microbiol 2015; 6:313.

3. Garau J, Xercavins M, Rodríguez-Carballeira M, Gómez-Vera JR, Coll I, Vidal D, et al. Emergence and dissemination of quinolone-resistant Escherichia coli in the community. Antimicrob Agents Chemother 1999;43: 2736-41.

4. Li B, Sun JY, Liu QZ, Han LZ, Huang XH, Ni YX. High prevalence of CTX-M $\beta$-lactamases in faecal Escherichia coli strains from healthy humans in Fuzhou, China. Scand J Infect Dis 2011;43:170-4.

5. Le TM, Baker S, Le TP, Le TP, Cao TT, Tran TT, et al. High prevalence of plasmid-mediated quinolone resistance determinants in commensal members of the Enterobacteriaceae in Ho Chi Minh City, Vietnam. J Med Microbiol 2009; 58:1585-92.

6. Jacoby GA, Strahilevitz J, Hooper DC. Plasmid-mediated quinolone resistance. Microbiol Spectr 2014;2, doi: 10.1128/microbiolspec.PLAS0006-2013.

7. Musumeci R, Rausa M, Giovannoni R, Cialdella A, Bramati S, Sibra B, et al. Prevalence of plasmid-mediated quinolone resistance genes in uropathogenic Escherichia coli isolated in a teaching hospital of northern Italy. Microb Drug Resist 2012;18:33-41.

8. Rodríguez-Martínez JM, Cano ME, Velasco C, Martínez-Martínez L, Pascual A. Plasmid-mediated quinolone resistance: an update. J Infect Chemother 2011;17:149-82.

9. CLSI. Performance Standards for Antimicrobial Susceptibility Testing. 24th ed. CLSI supplement M100-S26. Wayne, PA: Clinical and Laboratory Standards Institute; 2016. 